\title{
PARTISIPASI KELOMPOK MASYARAKAT DALAM PENGELOLAAN KAWASAN HUTAN LINDUNG, KASUS DI HUTAN LINDUNG GUNUNG NONA KOTA AMBON PROPINSI MALUKU
}

\author{
Community Participation in Managing Protected Forest Area \\ Case in Gunung Nona Protection Forest in Ambon - Maluku Province \\ Messalina L Salampessy, Bramasto Nugroho, Herry Purnomo
}

\begin{abstract}
The management of a protection forest often faces a dilemma between the importance of conservation and the importance of the needs of the local people in the area. Managing the area will on't be so effective and disturbed if there is only minimal participation and insufficient support in interaction from the local people. Various factors of heterogeneous people will influence the form of interaction that occurs between the people and the area. The aim of this study is to know and measure the participation of the local people in managing the protection forest and to analyse the characteristics (both individual and organizational) that influence the level of participation collectively in preserving the protected forest area. This research is designed as a survey research having the character of a descriptive co-relationship between the variable dependent i.e. Community participation and the variable of individual and organizational characters as a heterogeneous factor in protection forest area. This research population is the active community who manage the land (dusung) around the protection forest area in Gunung Nona (HLGN) in Ambon. Data analyses used tests the technical Chi square and its participation level test the co-efficient of the contingency. Results show that the characteristics (both individual and organizational) that have a close connection and influenced the level of participation in preserving the HLGN area are their knowledge about the protection forest, the scope of the authority of dusung land, the status of ownership of the dusung, the period of involvement in the organization and the relationship between the organizer and the public members in the organization. People's participation in managing the HLGN is based on the perceived benefits and how they manage the dusung depends on their own character or morale.
\end{abstract}

Key words: Participation, Heterogeneous, Dusung.

\section{PENDAHULUAN}

Pada beberapa kawasan hutan lindung, interaksi antar masyarakat lokal dengan sumberdaya alam masih sangat kuat. Bahkan di beberapa lokasi, pola interaksi yang terjalin memberikan kecenderungan positif terhadap kelestarian hutan MacKinnon, et al. (1990). Upaya untuk berpartisipasi senantiasa diinginkan oleh masyarakat, namun demikian hingga saat ini peran partisipasi belum sepenuhnya optimal masih pada tahapan menginformasikan dari tahapan tangga partisipasi yang diharapkan (Arnstein, 1995) dalam Komite PPA-MFP (2006). Partisipasi masyarakat adalah suatu proses yang memberi kesempatan kepada masyarakat secara individu atau kelompok untuk mempengaruhi keputusan publik termasuk di dalamnya kesempatan berpartisipasi dalam pengelolaan hutan (Cohan and Sharp, 1995) dalam (Poteete and Ostrom, 2004).

Seperti halnya kawasan hutan lindung lainnnya, Hutan Lindung Gunung Nona (HLGN) di Kota Ambon menghadapi tekanan populasi penduduk yang terus bertambah dan persoalan sosial-ekonomi yang harus dipenuhi dan cenderung meningkat. Di sisi lain, pemerintah menetapkan konsep hutan lindung yang pada prinsipnya memiliki perbedaan dengan konsep pengelolaan sumberdaya alam masyarakat pada kedua desa (desa Amahusu dan Urimesing) yang tepat berada di kawasan hutan ini. Adapun 
perbedaan yang pertama pada pemberlakuan sistem dusung dan perbedaan yang kedua terletak pada defenisi tentang hak penguasaan (property right), yang menyebabkan lebih dari $80 \%$ wilayah pengelolaan dusung ditetapkan oleh pemerintah sebagai kawasan hutan lindung.

Permasalahan yang dialami oleh HLGN terjadi pula di beberapa lokasi kawasan konservasi dan hutan lindung, misalnya konflik antara masyarakat lokal dengan taman nasional di TN Komodo, TN Siberut dan TN Lauser (Iskandar, 1992) dalam (Golar, 2007). Permasalahan yang terjadi di HLGN maupun di tempat lain merupakan masalah kelembagaan terutama menyangkut hak penguasaan dan pengelolaan sumberdaya alam antara pemerintah dan masyarakat lokal dimana aspek partisipasi diupayakan sebagai salah satu jalan keluar dari persoalan ini. Banyak faktor mempengaruhi bentuk partisipasi masyarakat, dimana salah satunya adalah aspek heterogenitas dan karakteristik masyarakat itu sendiri.

Terdapat sejumlah kajian terdahulu tentang faktor heterogenitas yang mempengaruhi bentuk partisipasi masyarakat dalam pengelolaan kawasan hutan dengan fokus dan tujuan yang beragam (Gibson and Koontz (1998); Varughese. (1999, 2000); Gibson (2000); Gibson \& Becker (2000); Varughese \& Ostrom (2001) dalam (Poteete and Elinor, 2004), membuktikan bahwa heterogenitas berpengaruh pada bentuk pengelolaan dan ketertarikan masyarakat dalam pengelolaan hutan. Selain itu, terdapat pula kajian yang mempertanyakan perihal kemampuan masyarakat lokal dalam mengelola dan mempertahankan kelestarian sumberdaya alam Maertens et al. (2002); Sitorus (2004) dalam Golar (2007).

Kajian-kajian tersebut di atas telah menjelaskan tentang partisipasi dengan berbagai faktor yang mempengaruhi aktivitas keterlibatan masyarakat. Namun demikian, kajian-kajian tersebut belum mampu menjelaskan bagaimana peran partisipasi masyarakat, heterogenitas serta karakteristik individu dan organisasi itu terhadap efektivitas pencapaian partisipasi masyarakat dalam pengelolaan kawasan tersebut sehingga pentingnya penelitian ini dilakukan.

\section{BAHAN DAN METODE}

\section{Desain Penelitian}

Penelitian ini didesain sebagai suatu penelitian survai yang bersifat deskriptif korelasional. Variabel dependen penelitian adalah partisipasi masyarakat dalam kegiatan perencanaan, pelaksanaan, penerimaan manfaat serta monitoring dan evaluasi terhadap kawasan hutan lindung. Sedangkan variabel independennya adalah kelompok variabel faktor individu dan faktor organisasi yang merupakan karakteristik masyarakat. Faktor individu adalah variabel: (1) pengetahuan tentang hutan lindung, (2) luas penguasaan lahan hutan, (3) status pemilikan lahan hutan, (4) pendapatan dari pengusahaan lahan dusung, (5) nilai aset (6) identitas daerah asal responden, (7) tingkat pendidikan, (8) umur, (9) jumlah tanggungan, (10) lama keterlibatan dalam organisasi. Sedangkan faktor organisasi adalah variabel: (1) persepsi tentang organisasi (komunikasi dan informasi, pemahaman aturan organisasi, pengambilan keputusan, penyelesaian masalah), (2) hubungan pengurus dan anggota organisasi.

Populasi penelitian ini adalah kelompok masyarakat yang aktif dalam pengelolaan lahan (dusung) di sekitar kawasan Hutan Lindung Gunung Nona Kota Ambon dan berbagai pihak yang terlibat dalam pengelolaan kawasan yang akan diidentifikasi dengan cara analisis stakeholder. Unit analisis penelitian ini adalah individu yaitu masyarakat pengelola dusung dan untuk memahami faktor-faktor yang mempengaruhi tingkat partisipasi mereka dalam kegiatan pengelolaan kawasan. Jumlah sampel masyarakat pada setiap desa sampel sebanyak 30 orang untuk tiap desa yang mana didasari pada jumlah pemilik dusung pada tiap desa \pm 50 orang dan dipilih secara sengaja (purposive sampling). Pengumpulan data dalam penelitian ini dilakukan dengan wawancara dan kuesioner. 


\section{Metode Analisis Data}

Menurut Djarwanto dan Sudjana (1996) dalam Yudilastiantoro (2005), untuk menggambarkan hubungan antara karakteristik responden (heterogenitas) dan tingkat partisipasinya digunakan analisis distribusi frekuensi dengan tabulasi silang yang kemudian diuji dengan teknik Chi Square dengan rumus sebagai berikut :

$$
X^{2}=\frac{\left(f_{o}-f_{h}\right)^{2}}{f_{h}}
$$

dimana: $X^{2}=$ uji chi kuadrat

fo = nilai yang diamati (nilai observasi)

fh = nilai yang diharapkan (nilai harapan)

Pengujian signifikansi antara tingkat partisipasi dengan faktor heterogenitas dilakukan dengan membandingkan nilai $X^{2}$ hitung dengan $X^{2}$ tabel dengan kriteria sebagai berikut :

a. Jika $X^{2}$ hitung $>X^{2}$ tabel berarti variabel heterogenitas mempunyai hubungan dengan tingkat partisipasinya.

b. Jika $X^{2}$ hitung $<X^{2}$ tabel berarti variabel heterogenitas tidak mempunyai hubungan dengan tingkat partisipasinya.

Untuk mengetahui derajat keeratan hubungan antara variabel bebas (heterogenitas) dengan variabel terikat (tingkat partisipasi) maka digunakan uji koefisien kontingensi dengan rumus Sudjana (1996) dalam Yudilastiantoro (2005) :

$$
C=\frac{X^{2}}{X^{2}+n}
$$

$$
\begin{aligned}
\operatorname{dimana}: \mathrm{C} & =\text { koefisien kontingensi } \\
\mathrm{x}^{2} & =\text { nilai } \mathrm{x} 2 \text { hitung } \\
\mathrm{n} & =\text { jumlah responden }
\end{aligned}
$$

Nilai $C$ berkisar antara $0-1,00$ dan semakin besar nilai $C$ berarti hubungan antara dua variabel makin erat. Pedoman untuk memberikan interpretasi koefisien kontigensi digunakan batasan yang dikemukan oleh Sugiono (2007) seperti disajikan pada Tabel 1.

Table 1 The Value of Correlation Coefficients and Level of Relationship

\begin{tabular}{cc}
\hline Rate Coefficient & Interval Relation \\
\hline $0,00-0,199$ & Sangat rendah \\
$0,20-0,399$ & Rendah \\
$0,40-0,599$ & Sedang \\
$0,60-0,799$ & Kuat \\
$0,80-1.00$ & Sangat kuat \\
\hline
\end{tabular}

Sumber : Sugiono, 2007

\section{HASIL DAN PEMBAHASAN}

\section{Karakteristik Individu}

Karakteristik individu sebagai kelompok variabel independen dalam penelitian ini terdiri atas: (1) pengetahuan tentang HLGN, (2) luas lahan dusung garapan, (3) status pemilikan lahan dusung, (4) pendapatan per tahun responden, (5) umur responden, (6) lama keterlibatan dalam organisasi masyarakat, (7) pendidikan responden, (8) nilai aset/kekayaan, (9) jumlah tanggungan keluarga dan (10) identitas asal responden. Keragaman setiap variabel tersebut secara deskriptif dipaparkan pada Tabel 2.

\section{Karakteristik Organisasi}

Variabel yang dikelompokkan ke dalam kelompok variabel karakteristik organisasi adalah : (1) persepsi tentang organisasi yang meliputi komunikasi dan informasi, pemahaman aturan organisasi, pengambilan keputusan, penyelesaian masalah, (2) hubungan pengurus dengan anggota. Keragaan setiap variabel tersebut tertera pada Tabel 3.

\section{Partisipasi Responden}

Variabel dependen penelitian ini adalah partisipasi masyarakat di sekitar kawasan hutan lindung. Adapun hasilnya tercantum pada Tabel 4 
Table 2. The Diversity of Individual Characteristics of the Hamlet Community Organizer

\begin{tabular}{|c|c|c|c|c|}
\hline Description of individual Characteristics & $\begin{array}{l}\text { Amahusu } \\
\text { Village }\end{array}$ & $\begin{array}{l}\text { Urimesing } \\
\text { Village }\end{array}$ & $\begin{array}{l}\text { Total Amount } \\
\text { (people) }\end{array}$ & $\begin{array}{l}\text { Percentage } \\
(\%)\end{array}$ \\
\hline \multicolumn{5}{|l|}{ Pengetahuan tentang HLGN } \\
\hline Sangat kurang memahami & 5 & 8 & 13 & 21.67 \\
\hline Kurang memahami & 6 & 5 & 11 & 18.33 \\
\hline Cukup baik memahami & 5 & 7 & 12 & 20.00 \\
\hline Sangat baik memahami & 14 & 10 & 24 & 40.00 \\
\hline \multicolumn{5}{|l|}{ Luas Penguasaan dusung } \\
\hline \multicolumn{5}{|l|}{$\begin{array}{l}\text { a. Penggolongan berdasarkan standar luas } \\
\text { dusung }\end{array}$} \\
\hline Dusung luas (2,5-5 ha) & 5 & 7 & 12 & 20 \\
\hline Dusung sedang (1-2,5 ha) & 12 & 5 & 17 & 28.33 \\
\hline Dusung sempit (<1 ha) & 13 & 18 & 31 & 51.67 \\
\hline \multicolumn{5}{|l|}{$\begin{array}{l}\text { b. Penggolongan berdasarkan kelompok } \\
\text { responden }\end{array}$} \\
\hline Dusung sempit (<1 ha) & 13 & 18 & 31 & 51.67 \\
\hline Dusung Luas ( $1-5$ ha) & 17 & 12 & 29 & 48.33 \\
\hline \multicolumn{5}{|l|}{ Status Pemilikan lahan dusung } \\
\hline Dusung adat & 11 & 9 & 20 & 33.33 \\
\hline Dusung milik sendiri dengan sertifikat & 2 & 5 & 7 & 11.67 \\
\hline Dusung disewa. & 0 & 0 & 0 & 0.00 \\
\hline Tanpa status & 16 & 16 & 32 & 53.33 \\
\hline \multicolumn{5}{|l|}{ Pendapatan dari dusung } \\
\hline rendah (1 - 5 juta) & 12 & 14 & 26 & 43.33 \\
\hline tinggi (5- 10 juta) & 18 & 16 & 34 & 56.67 \\
\hline \multicolumn{5}{|l|}{ Umur } \\
\hline Muda (30-45) & 3 & 5 & 8 & 13.33 \\
\hline Tua $(47-72)$ & 27 & 25 & 52 & 86.67 \\
\hline \multicolumn{5}{|l|}{ Keterlibatan dalam organisasi } \\
\hline Keanggotaan baru (1-4 thn) & 3 & 2 & 5 & 8.33 \\
\hline Keanggotaan lama (4-6 thn) & 27 & 28 & 55 & 91.67 \\
\hline \multicolumn{5}{|l|}{ Tingkat pendidikan } \\
\hline SD & 4 & 4 & 8 & 13.33 \\
\hline SMP & 8 & 9 & 17 & 28.33 \\
\hline SMU & 18 & 16 & 34 & 56.67 \\
\hline Univ/akademi & 0 & 1 & 1 & 1.67 \\
\hline \multicolumn{5}{|l|}{ Nilai asset } \\
\hline $5-10 \mathrm{jt}$ & 13 & 11 & 24 & 40.00 \\
\hline $10-20$ jt & 10 & 15 & 25 & 41.67 \\
\hline$>20 \mathrm{jt}$ & 7 & 4 & 11 & 18.33 \\
\hline
\end{tabular}


Table 2. Continue

\begin{tabular}{|c|c|c|c|c|}
\hline Description of individual Characteristics & $\begin{array}{c}\text { Amahusu } \\
\text { Village }\end{array}$ & $\begin{array}{l}\text { Urimesing } \\
\text { Village }\end{array}$ & $\begin{array}{l}\text { Total Amount } \\
\text { (people) }\end{array}$ & $\begin{array}{c}\text { Percentage } \\
(\%)\end{array}$ \\
\hline \multicolumn{5}{|l|}{ Jumlah tanggungan } \\
\hline $1-4$ org & 8 & 5 & 13 & 21.67 \\
\hline $5-8$ org & 22 & 23 & 45 & 75.00 \\
\hline$>8$ org & 0 & 2 & 2 & 3.33 \\
\hline \multicolumn{5}{|l|}{ Identitas asal } \\
\hline Masyarakat Asli & 28 & 28 & 56 & 93.33 \\
\hline Pendatang (telah menetap lama) & 1 & 2 & 3 & 5.00 \\
\hline Pengungsi (menetap karena konflik) & 1 & 0 & 1 & 1.67 \\
\hline
\end{tabular}

Table 3. Communitv Oraanizations Manaaina Diversitv Characteristic Hamlet

\begin{tabular}{|c|c|c|c|c|}
\hline $\begin{array}{c}\text { Description of Organization } \\
\text { Characteristics } \\
\end{array}$ & $\begin{array}{l}\text { Amahusu } \\
\text { Village }\end{array}$ & $\begin{array}{l}\text { Urimesing } \\
\text { Village }\end{array}$ & $\begin{array}{l}\text { Total Amount } \\
\text { (people) }\end{array}$ & $\begin{array}{c}\text { Percentage } \\
(\%)\end{array}$ \\
\hline \multicolumn{5}{|l|}{$\begin{array}{l}\text { Presepsi tentang organisasi } \\
\text { a.Komunikasi \& informasi }\end{array}$} \\
\hline kurang baik & 0 & 0 & 0 & 0.00 \\
\hline cukup baik & 0 & 8 & 8 & 13.33 \\
\hline baik & 24 & 22 & 46 & 76.67 \\
\hline sangat baik & 0 & 0 & 0 & 0.00 \\
\hline \multicolumn{5}{|l|}{ b. Pemahaman aturan organisasi } \\
\hline tidak paham & 0 & 2 & 2 & 3.33 \\
\hline sedikit paham & 1 & 7 & 8 & 13.33 \\
\hline cukup paham & 10 & 11 & 21 & 35.00 \\
\hline sangat paham & 11 & 10 & 21 & 35.00 \\
\hline \multicolumn{5}{|l|}{ c. Pengambilan keputusan } \\
\hline kurang baik & 0 & 2 & 2 & 3.33 \\
\hline cukup baik & 0 & 1 & 1 & 1.67 \\
\hline baik & 20 & 26 & 46 & 76.67 \\
\hline sangat baik & 4 & 1 & 5 & 8.33 \\
\hline \multicolumn{5}{|l|}{ d.Penyelesaian masalah } \\
\hline kurang baik & 0 & 0 & 0 & 0.00 \\
\hline cukup baik & 16 & 9 & 25 & 41.67 \\
\hline baik & 2 & 21 & 23 & 38.33 \\
\hline \multicolumn{5}{|l|}{ Hubungan pengurus dengan anggota } \\
\hline kurang baik & 0 & 7 & 7 & 11.67 \\
\hline cukup baik & 11 & 4 & 15 & 25.00 \\
\hline baik & 12 & 14 & 26 & 43.33 \\
\hline
\end{tabular}


Table 4. Respondent's Participation in the Management Protection Forest

\begin{tabular}{|c|c|c|c|c|c|c|c|c|c|c|c|c|c|}
\hline \multirow[t]{2}{*}{ No } & \multirow[t]{2}{*}{ Indicator Assessment } & \multicolumn{3}{|c|}{$\begin{array}{l}\text { Amahusu } \\
\text { Village }\end{array}$} & \multicolumn{3}{|c|}{$\begin{array}{l}\text { Urimesing } \\
\text { Village }\end{array}$} & \multicolumn{3}{|c|}{ Total } & \multicolumn{3}{|c|}{ Percentage (\%) } \\
\hline & & $\mathrm{H}$ & $M$ & $\mathrm{~L}$ & $\mathrm{H}$ & $M$ & $\mathrm{~L}$ & $\mathrm{H}$ & $M$ & L & $\mathrm{H}$ & $\mathrm{M}$ & $L$ \\
\hline & Perencanaan & & & & & & & & & & & & \\
\hline 1 & Kegiatan survey & 3 & 12 & 15 & 4 & 12 & 14 & 7 & 24 & 29 & 11.67 & 40.0 & 48.3 \\
\hline 2 & Pemberian informasi & 1 & 8 & 21 & 1 & 8 & 21 & 2 & 16 & 42 & 3.33 & 26.6 & 70.0 \\
\hline 3 & Pengajuan usul \& Saran & 3 & 13 & 14 & 4 & 10 & 16 & 7 & 23 & 30 & 11.67 & 38.3 & 50.0 \\
\hline & Pelaksanaan & & & & & & & & & & & & \\
\hline 1 & $\begin{array}{l}\text { Pemberian sumbangan } \\
\text { pikiran }\end{array}$ & 1 & 17 & 12 & 1 & 11 & 18 & 2 & 28 & 30 & 3.33 & 46.6 & 50.0 \\
\hline 2 & $\begin{array}{l}\text { Pemberian sumbangan } \\
\text { tenaga }\end{array}$ & 6 & 16 & 8 & 2 & 11 & 17 & 8 & 27 & 25 & 13.33 & 45.0 & 41.6 \\
\hline 3 & $\begin{array}{l}\text { Pemberian sumbangan } \\
\text { materi }\end{array}$ & 0 & 4 & 26 & 2 & 2 & 26 & 2 & 6 & 52 & 3.33 & 10.0 & 86.6 \\
\hline & Penerimaan Manfaat & & & & & & & & & & & & \\
\hline 1 & Peningkatan pendapatan & 10 & 18 & 2 & 12 & 13 & 5 & 22 & 31 & 7 & 36.67 & 51.6 & 11.6 \\
\hline 2 & Manfaat hutan & 1 & 18 & 11 & 0 & 30 & 0 & 1 & 48 & 11 & 1.67 & 80.0 & 18.3 \\
\hline 3 & $\begin{array}{l}\text { Ketergantungan terhadap } \\
\text { hutan }\end{array}$ & 0 & 28 & 2 & 1 & 27 & 2 & 1 & 55 & 4 & 1.67 & 91.6 & 6.6 \\
\hline & Monitoring dan Evaluasi & & & & & & & & & & & & \\
\hline 1 & Monitoring Hutan lindung & 3 & 8 & 19 & 2 & 6 & 22 & 5 & 14 & 41 & 8.33 & 23.3 & 68.3 \\
\hline 2 & Mengawasi hutan lindung & 2 & 10 & 18 & 1 & 3 & 26 & 3 & 13 & 44 & 5.00 & 21.6 & 73.3 \\
\hline 3 & Mengevaluasi hutan lindung & 1 & 4 & 25 & 1 & 4 & 25 & 2 & 8 & 50 & 3.33 & 13.3 & 83.3 \\
\hline
\end{tabular}

Ket $: H=$ tinggi, $M=$ Sedang dan $L=$ rendah

\section{Hubungan antara Karakteristik Responden dengan Partisipasi Masyarakat dalam Kegiatan Pengelolaan HLGN}

Hubungan karakteristik responden dengan partisipasi masyarakat dalam pengelolaan kawasan HLGN dikaji berdasarkan analisis Chi Square $\left(X^{2}\right)$ dan digunakan uji Koefisien Kontigensi/Keeratan (C). Nilai $X^{2}$ dan Koefisien Keeratan hubungan dari masing-masing variabel heterogenitas dari kedua desa dapat dilihat pada Tabel 5 dan 6.

Pada Tabel 5 dan 6 terlihat bahwa karakteristik individu dan organisasi yang mempunyai hubungan erat dan berpengaruh terhadap partisipasi masyarakat dalam pengelolaan kawasan HLGN adalah pengetahuan tentang hutan lindung, luas penguasaan lahan dusung, status pemilikan dusung, lama keterlibatan dalam organisasi serta hubungan pengurus dan anggota masyarakat dalam organisasi. Seperti halnya institusi lokal, seperti harta karun yang potensinya belum termanfaatkan, demikian juga pengetahuan masyarakat. Masyarakat setempat memiliki pengetahuan yang luas tentang hutan itu (terutama dusung dengan kawasan hutan di sekitarnya) karena pengalaman pribadi dan pengamatan jangka panjang dan juga pelajaranpelajaran nyata dari orangtua dan nenek moyang mereka. Pengetahuannya itu tidak selalu nyata dan merata di antara kelompok masyarakat yang hidup pada hutan lindung itu. Memahami potensi pengetahuan setempat, pemahaman mereka tentang hutan, dari siapa diperolehnya dan mengetahui cara untuk mengaksesnya merupakan tugas penting untuk mengkatalisator partisipasi dan aksi bersama (Colfer, 2000). Penyatuan pengetahuan setempat dan luar penting dilakukan. Pertukaran berbagai jenis pengetahuan sangat produktif bagi berbagai pihak yang berkepentingan bagi kawasan HLGN tersebut. 
Table 5. Relations with The Participation of Various Respondent Characteristic to The Amahusu

\begin{tabular}{|c|c|c|c|c|}
\hline No & $\begin{array}{l}\text { Reletionship participation with } \\
\text { characteristic }\end{array}$ & $X^{2}$ Value & C value & Relations and the level of relationship \\
\hline 1 & Umur & 3,600 & 0,327 & Tidak ada \\
\hline 2 & Pendidikan & 0,764 & 0,158 & Tidak ada \\
\hline 3 & Jumlah tanggungan keluarga & 1,765 & 0,236 & Tidak ada \\
\hline 4 & Pengetahuan & 25,378 & 0,677 & Ada hubungan/kuat \\
\hline 5 & Luas dusung & 12,573 & 0,543 & Ada hubungan/sedang \\
\hline 6 & Status pemilikan & 16,223 & 0,592 & Ada hubungan/sedang \\
\hline 7 & Pendapatan & 1,536 & 0,221 & Tidak ada \\
\hline 8 & Nilai aset & 9,143 & 0,483 & Tidak ada \\
\hline 9 & $\begin{array}{l}\text { Lama keterlibatan dalam } \\
\text { organisasi }\end{array}$ & 17,400 & 0,648 & Ada hubungan/kuat \\
\hline 10 & Hubungan di dalam organisasi & 13,010 & 0,593 & Ada hubungan/sedang \\
\hline 11 & Komunikasi dan Informasi & 0 & 0 & Responden menilai baik \\
\hline 12 & Pemahaman aturan organisasi & 3,152 & 0,341 & Tidak ada \\
\hline 13 & Pangambilan keputusan & 3,000 & 0,333 & Tidak ada \\
\hline 14 & Penyelesaian masalah & 9,611 & 0,535 & Ada hubungan/sedang \\
\hline
\end{tabular}

Table 6. Relation with the Participation of Various Characteristic, $X^{2}$ Value, The C Coefficient and Their Level of Relationship to The Urimesing Village.

\begin{tabular}{llccc}
\hline No & $\begin{array}{c}\text { Relationship participation with } \\
\text { characteristic }\end{array}$ & X' Value & C Value & Relations and the level of relationship \\
\hline 1 & Umur & 5,250 & 0,386 & Tidak ada \\
2 & Pendidikan & 8,125 & 0,462 & Tidak ada \\
3 & Jumlah tanggungan keluarga & 2,689 & 0,287 & Tidak ada \\
4 & Pengetahuan & 15,910 & 0,589 & Ada hubungan/sedang \\
5 & Luas dusung & 14,820 & 0,575 & Ada hubungan/sedang \\
6 & Status pemilikan & 16,207 & 0,592 & Ada hubungan/sedang \\
7 & Pendapatan & 8,693 & 0,474 & Ada hubungan/sedang \\
8 & Nilai aset & 22,033 & 0,651 & Ada hubungan/kuat \\
9 & Lama Keterlibatan dalam & 6,562 & 0,424 & Ada hubungan/sedang \\
& organisasi & & & \\
10 & Hubungan di dalam organisasi & 19,890 & 0,631 & Ada hubungan/kuat \\
11 & Komunikasi dan Informasi & 1,643 & 0,228 & Tidak ada \\
12 & Pemahaman aturan organisasi & 7,710 & 0,452 & Tidak ada \\
13 & Pengambilan keputusan & 4,038 & 0,344 & Tidak ada \\
14 & Penyelesaian masalah & 0,067 & 0,047 & Tidak ada \\
\hline
\end{tabular}

Status pemilikan dusung adalah perorangan dan memiliki fungsi produksi untuk memenuhi kebutuhan keluarga. Masyarakat telah mempertahankan fungsi dusung ini dari generasi ke generasi. Status pemilikannya perorangan dan keluarga, dimana ada yang telah disertifikasi dan ada yang tanpa status. Tidak mudah mengatasi persoalan ini, upaya penyelesaian yang diusahakan oleh masyarakat adalah dengan mengeratkan hubungan kekerabatan (antar marga yang diberi hak atas kepemilikan dusung) sehingga dengan demikian ada institusi (hubungan kekerabatan itu) yang mengatur hakhak individu, hak-hak bersama dan mengatur fungsinya. Sistem pengelolaan hutan seperti ini bukan hanya mewujudkan orientasi keuntungan individu pengelola, melainkan juga memperhatikan kepentingan bersama dan fungsi kawasan hutan itu sendiri (Kartodihardjo, 2006). Luas penguasaan dusung dan status pemilikannya tidak akan menjadi hambatan bagi upaya membangun partisipasi yang ada, justru 
partisipasi akan membantu mengatur mekanisme institusi lokal tersebut. Institusi lokal membantu mewujudkan keadilan dimana di samping memegang hak, individu juga memegang tanggung jawab. Hak individu diperoleh dan diakui oleh anggota masyarakat sehingga dipegang secara aman, karena individu juga diberi tanggung jawab untuk kepentingan bersama (menjaga kondisi hutan sekitarnya). Mekanisme keadilan mendorong masyarakat membantu mengamankan dan menuntut keberadaan sumberdaya hutan lindung tersebut tetap terjaga.

Aturan main yang mengatur hubungan antar manusia untuk menghambat munculnya perilaku oportunistik dan saling merugikan (free riding dan asimetrik informasi) selalu berusaha diatasi antar pemilik dusung. Salah satu cara mengatasinya adalah membangun keterlibatan tiap individu dalam berorganisasi dan menciptakan hubungan kerja yang sesuai kepentingan bersama sehingga upaya untuk memaksimumkan kesejahteraan individu lebih dapat diprediksikan. Melalui organisasi, upaya membangun koordinasi termasuk pertukaran informasi dan berbagai hal serta efisiensi biaya dapat diatasi. Hal ini sejalan dengan yang dikemukan oleh Agrawal dan Gibson (1999) bahwa lebih seringnya interaksi-interaksi dapat menurunkan biaya-biaya untuk bagaimana membuat keputusan-keputusan yang kolektif tersebut. Untuk itulah maka partisipasi memberikan pilihan untuk aspirasi tiap individu dan sangat mempengaruhi kebijakan yang dibuat.

Arnstein (1995) dalam Komite PPA-MFP et all. (2006) menyatakan bahwa tingkat partisipasi sangat bervariasi mulai tahap manipulasi, terapi, menginformasikan, konsultasi, menentramkan, kemitraan, delegasi kekuasaan hingga kontrol masyarakat. Tingkatan tersebut dikenal dengan istilah tangga partisipasi. Tangga partisipasi ini akan sangat membantu mempelajari sejauhmana tingkat peran partisipasi yang dimainkan oleh masyarakat dan bagaimana membuatnya lebih baik. Untuk tangga partisipasi yang terlihat pada bentuk peran serta masyarakat dalam pengelolaan kawasan HLGN telah berada pada tangga menginformasikan dan tangga kemitraan dimana masyarakat disosialisasikan dan diinformasikan tentang fungsi dan manfaat kawasan HLGN dengan harapan mereka memahami dan berpartisipasi menjaga kelestarian kawasan dan sebagai mitra kerja dalam pengelolaan kawasan ini. Tingkat partisipasi ini belumlah optimal seperti yang diharapkan karena upaya menginformasikan lebih dikhususkan pada pemimpin mereka begitupun keikutsertaan sebagai mitra kerja relatif hanya pada proyek penanaman dan pemeliharaan tanaman reboisasi.

Kawasan HLGN yang sangat dekat dengan Kota Ambon secara tidak langsung mengakibatkan kawasan ini mengalami tekanan sebagai implikasi dari terganggunya performansi tersebut. Gambaran terjadinya degradasi terhadap sumberdaya yang ada tentunya mengakibatkan fungsi hidrologi HLGN terganggu. Upaya mengatasinya dilakukan oleh pemerintah Kota Ambon khususnya Dinas Kehutanan dengan memfungsikan kembali kewang pada masingmasing dusung.

Masyarakat kedua desa memiliki homogenitas pada aspek budaya (adat Maluku) dan minat ekonomi (sistem pengelolaan dusungnya), hal ini memudahkan menjalankan partisipasi dan meningkatkan partisipasi masyarakat dalam pengelolaan kawasan HLGN.

\section{KESIMPULAN}

(1) Partisipasi masyarakat dalam kegiatan perencanaan, pelaksanaan, penerimaan manfaat serta evaluasi dan monitoring terhadap kawasan HLGN masih tergolong rendah.

(2) Faktor karakteristik individu dan organisasi yang mempunyai hubungan erat dan berpengaruh terhadap partisipasi masyarakat dalam pengelolaan kawasan HLGN adalah pengetahuan tentang hutan lindung, luas penguasaan lahan dusung, status pemilikan dusung, lama keterlibatan dalam organisasi serta hubungan pengurus dan anggota masyarakat dalam organisasi.

(3) Masyarakat menampakkan partisipasi kalkulatif dalam peran mereka sebagai pengelola HLGN dan menampakkan partisipasi dengan ciri kepatuhan moral dalam peran mereka sebagai pengelola dusung.

(4) Pentingnya diciptakan partisipasi dan mata rantai aksi bersama berbagai stakeholder sehingga kelemahan dari tiap peran yang dimainkan oleh tiap stakeholder dapat saling melengkapi dan teratasi demi kelestarian HLGN dan kesejahteraan bersama.

\section{DAFTAR PUSTAKA}


Agrawal, A. and Gibson C. 1999. Enhancement and Disenhancement : The Role of Community in Natural Resource Conservation. World Development Vol. 27, No. 4, pp 629-649. Elservier Science.Ltd.

Colfer, JPC. 2000. Aturan-Aturan Sederhana Katalisasi Aksi Kolektif dalam Pengelolaan Sumberdaya Alam. CIFOR. Bogor.

Golar. 2007. Strategi Adaptasi Masyarakat Adat Toro. Kajian Kelembagaan Lokal dalam Pengelolaan dan Pemanfaatan Sumberdaya Hutan di Taman Nasional Lore Lindu Propinsi Sulawesi Tengah. Disertasi Institut Pertanian Bogor [Tidak Dipublikasikan]. Bogor.

Komite PPA-MFP. 2006. Kemitraan dalam Pengelolaan Taman Nasional : Pelajaran untuk Transformasi Kebijakan. Yayasan WWF-Indonesia.

Diterima : 22 Februari 2010

\section{Messalina L. Salampessy \\ Jurusan Kehutanan \\ Fakultas Pertanian Univeritas Pattimura \\ J. Puthena Kampus Poka. Ambon.}

\section{Bramasto Nugroho and Herry Purnomo}

Departemen Manajemen Hutan

Fakultas Kehutanan

Institut Pertanian Bogor-Bogor
Kartodihardjo, H. 2006. Ekonomi dan Institusi Pengelolaan Hutan. Telaah Lanjut Analisis Kebijakan Usaha Kehutanan. IDEALS. Gedung Alumni IPB Lantai 2. Bogor.

MacKinnon, JK, G. Child, J. Thorsell. 1990. Pengelolaan Kawasan yang Dilindungi di Daerah Tropika. Gadjah Mada University Press. Yogyakarta.

Poteete, A. E. Ostrom. 2004. Heterogeneity, Group Size dan Collective Action : The Role of Institutions in Forest Management, Ford Foundation and National Science.

Sugiono. 2007. Statistika untuk Penelitian. Penerbit Alfabeta. Bandung.

Yudilastiantoro, C. 2005. Partisipasi Masyarakat terhadap Pengelolaan Hutan Lindung Di Das Palu (Hulu), Sulawesi Tengah. Info Sosial Ekonomi, Pusat Penelitian dan Pengembangan Sosial Ekonomi dan Kebijakan Kehutanan.Bogor. 